Metaphysical psychology from tragic athens

\title{
La psicología metafísica de la Atenas trágica
}

\author{
Mario Rosano Alloza \\ UNED \\ mrosanoalloza@gmail.com
}

DOI: https://doi.org/10.15366/bp.2020.24.022

Bajo Palabra. II Época. No 24. Pgs: 433-448

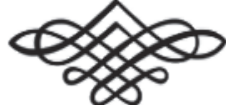


Recibido: 26/09/2018

Aprobado: 12/08/2020

\section{Resumen}

El presente artículo, a caballo entre la etnohistoria y la crítica literaria, pretende explicitar la psicología metafísica de la Atenas clásica a través de una de sus manifestaciones más emblemáticas: la tragedia. Para ello será necesario desentrañar la relación de este género literario con el dios que lo preside (Dioniso), y la relación de dicho dios con los acontecimientos y mutaciones políticas de la época.

Palabras clave: Tragedia, Dioniso, Atenas, Vernant.

\section{Abstract}

This article tries to explain the metaphysical psychology of the classical age of Athens through one of its most emblematic literary genres : tragedy. This requires to say the relationship between tragedy itself with the God who presides it (Dionysus), and the relationship between this god with the cultural and political situation of the time.

Keywords: Tragedy, Dionysus, Athens, Vernant. 


\section{Introducción}

CuANdo SE PIENSA EN LOS ORígenes más antiguos de la crítica literaria es habitual posar la mirada en escritos tan sobrios y analíticos como la Poética de Aristóteles aunque haya otros que, ajenos a ese talante, contienen en su seno valiosa información para quien se dedique a aquellos menesteres. Este es el caso de Las Ranas, una comedia del poeta Aristófanes que fue representada en la Atenas del año 405 a. C. Evidentemente tanto a una como a otra clase de textos les son extrańas estas categorías tan absolutamente modernas, que no hacen sino imponerles unos márgenes artificiales. La Poética plantea una reflexión acerca de la literatura, y el hecho de que todavía hoy siga siendo un texto vigente (es decir, aplicable a nuestras historias y a la manera en que las contamos) es un interesante problema que no trataremos aquí. Este texto de Aristóteles nos interesa en el mismo sentido en que nos interesa aquel otro de Aristófanes: por su capacidad para mostrar el papel que la poesía jugaba en la antigua Grecia y, más en particular, por su capacidad para desvelar la idiosincrasia de la tragedia, que es lo que constituye nuestro verdadero objeto de estudio.

En Las Ranas, Aristófanes retrata a un Dioniso que, ataviado como su hermano Heracles, se adentra en los infiernos para rescatar al poeta Eurípides, que acaba de morir. La finalidad del viaje y del rescate es resucitar, junto con el poeta, a la propia tragedia, ahora en decadencia. Tras una serie de acontecimientos y una vez en el Hades, Dioniso se ve en la tesitura de erigirse como juez ante la siguiente situación: Eurípides quiere disputar a Esquilo el trono de la tragedia. Con motivo de este juicio, y para acabar de una vez por todas con sus peleas, ambos poetas se enfrentan entre sí para ganarse el favor del dios, que no solo escogerá al mejor sino que, matando dos pájaros de un tiro, también le elegirá para resucitarle y devolver así el esplendor trágico a la ciudad de Atenas. El enfrentamiento entre uno y otro es muy ilustrativo ${ }^{1} \mathrm{y}$ además saca a la luz numerosos aspectos técnicos y formales de la tragedia a través de las muchas parodias que lo conforman. Más allá de esto, dicho enfrentamiento deja entrever aquellas funciones sociales que pueden ser atribuidas a la propia tragedia (tal como dice el coro):

\footnotetext{
Máxime si tenemos en cuenta que una vez Dioniso elige a Esquilo como ganador, este propone a su amigo Sófocles para ocupar aquel trono. Las importantes diferencias entre el proceder trágico de unos y de otro son de sobra conocidas en nuestro gremio gracias a Nietzsche, y quizás en otro sitio nos ocupemos de ellas. De momento baste con echar un vistazo a la antístrofa del coro que se cita unas líneas más abajo para refrescar la memoria.
} 
(Estrofa)

Feliz el hombre que tiene

refinada inteligencia.

Por muchas razones se comprende.

Pues el que parece cuerdo

otra vez se marcha de regreso a casa

para provecho de los ciudadanos,

para provecho de sus propios

familiares y amigos,

por ser sensato.

(Antistrofa)

Por tanto, es grato no charlar

sentado junto a Sócrates,

desatendiendo la música

e ignorando las grandes cosas

del arte trágico.

Pasar el tiempo con discursos

engolados y picoteros

de cosas inútiles es

propio de un hombre demente.

(Aristófanes: 2005, 232-233)

También muestra las que pueden ser atribuidas a la poesía en general (en boca del Esquilo de Las Ranas):

y eso es lo que deben practicar los poetas, pues mira lo útiles que han sido desde el principio los nobles poetas. Orfeo nos reveló misterios y a rehusar lo cruento, Museo nos aleccionó en enfermedades y oráculos, Hesíodo en el cultivo de la tierra, en las épocas de cosecha y de arado. El divino Homero, ¿de dónde obtuvo honra y fama si no es porque enseñó cosas útiles: disciplina, valor y el armamento de los hombres? (Aristófanes: 2005, 208-209)

Ante estos y otros pasajes de nuestra comedia cabe mostrar sorpresa y admiración respecto de la noción de utilidad, ajena a la mirada moderna (o más bien romántica) bajo la cual la poesía va ligada fundamentalmente al placer estético ${ }^{2}$. No le negamos su utilidad, por ejemplo, a la poesía de emergencia que Rafael Alberti recitaba a los soldados republicanos durante la Guerra Civil Espańola, como

\footnotetext{
${ }^{2}$ A este respecto nos parece útil señalar también las palabras que Sócrates le dirige a lón en el diálogo platónico homónimo:

¿No trata [Homero] con detalle y muy a menudo de la guerra, de las relaciones que mantienen entre sí los hombres buenos y los malos, los inexpertos en un oficio y los artesanos, sobre cómo se relacionan los dioses mutuamente y con los hombres, de qué modo se comportan, de lo que acontece en el cielo y en el Hades, y del nacimiento de los dioses y los héroes? (Platón: 2004, 32).
} 
tampoco le quitamos la razón a Martin Heidegger cuando dice que los soldados alemanes empaquetaban los himnos de Hölderlin junto a los utensilios de limpieza, pero en ningún caso esta utilidad significa lo mismo que aquella. En cuanto poesía, los poemas de Alberti o los himnos de Hölderlin quedan atrapados en el universo de la poesía.

En la antigua Grecia, sin embargo, la realidad cultural no se compartimenta en esferas tan separadas, de manera que la representación dramática es un acto a su vez ético y estético, político y religioso. A diferencia de la poesía moderna, hecha para ser leída y para quedar apresada en un libro, la poesía antigua (la épica, la lírica y la dramática) enmarca todos aquellos sentidos sociales en un acto cívico, cuya finalidad es enseñar a los ciudadanos cómo comportarse. Como dice Jean-Pierre Vernant a propósito de la épica: "Para los oyentes no se trata de un simple entretenimiento personal, de un lujo reservado a una élite instruida, sino una verdadera institución que hace las veces de memoria social, de un instrumento de conservación y comunicación del saber cuyo papel es decisivo" (Vernant: 2001, 17). El caso de la tragedia es un poco más complejo. Por ahora baste decir que al igual que su hermana mayor, nuestro género literario se dedica a situar al hombre de su tiempo en su relación con lo divino. A diferencia de ella, hay que decir que la tragedia ha de ser entendida como una auténtica invención: la épica tiene unas constricciones características, las cuales son en realidad reglas memotécnicas propias de una cultura oral, sin embargo la tragedia nace ya como obra escrita destinada a modificar el horizonte de la cultura griega en tres aspectos: el de las instituciones sociales, el de las formas literarias y el de la experiencia humana.

\section{Reconstruyendo la religión dionisíaca}

En su DicCionaRio de mitología gRiEga y ROMANA, Pierre Grimal nos presenta a Dioniso como al dios de la vińa, del vino y del delirio místico. Además, dice, es un dios complejo debido a la enorme mezcolanza de elementos prestados (griegos y extranjeros, viejos y nuevos) que componen su figura. Aun con todo parece que es propiamente griego y muy antiguo. Homero ya está familiarizado con él (si bien las referencias al

Más adentrado el diálogo, cuando Sócrates e Ión discuten acerca de la naturaleza divina o técnica del poeta y el rapsoda, Ión le responde a Sócrates lo siguiente acerca del supuesto tipo de cosas a las que se dedica la técnica del rapsoda (aunque al final de diálogo niegue que los rapsodas utilicen técnica alguna porque, al recitar, hablan por boca de la divinidad, la respuesta es bastante elocuente para lo que nos traemos entre manos): "Cuantas le conviene decir, por lo menos yo así lo creo, a un hombre y a una mujer, a un esclavo y a un hombre libre, a un gobernado y a un gobernante" (Platón: 2004, 45). Sirvan estas palabras para incidir, de nuevo, en la concepción de poesía como elemento social útil. 
dios en los poemas épicos son bastante escasas) y se dice que está ligado a ciertos cultos primitivos agrícolas y sacrificiales. Esta complejidad se hace eco incluso dentro del propio Olimpo, donde Dioniso no constituye un dios al uso: antes de acceder definitivamente a la morada de los dioses tiene que ser ataviado como una mujer y como una bestia para burlar a la celosa Hera, debido a que el pequeño es fruto de una infidelidad de Zeus. Efectivamente, su ascendencia es a medias mortal, lo que le confiere cierto carácter heroico a su figura. Tras vagar enloquecido por las tierras de Egipto y de Siria es purificado por Cibeles, quien le inicia en sus misterios. En Tracia ha de librar una de sus recurrentes batallas para liberarse de la ira de un rey que no acepta su culto, y más tarde, en la India, conforma definitivamente su cortejo triunfal ${ }^{3}$.

\subsection{Dioniso y el apelativo de lo otro:}

AdEMÁs DE SU CARÁCTER FEMENINo nuestro dios es señalado en numerosas ocasiones por su extranjería. Parece ser que esta cualidad traspasa incluso las fronteras del mito, que sitúa la acción de su infancia en la tierra de Nisos (la cual no se ha podido identificar con exactitud, pero en cualquier caso estaría fuera de la Hélade). Ciertos helenistas como Rohde (más famoso en nuestro gremio por su amistad Nietzsche que por su producción intelectual) también han querido situar la procedencia de su culto en Asia menor, tierra postulada con la finalidad de fijar un origen extranjero para el elemento perturbador (el orgíasmo) de un helenismo apolíneo ${ }^{4}$. Sea como fuere, Eurípides nos presenta a un Dioniso enmascarado vestido con ropas asiáticas y una perfumada melena femenina. Claro que el apelativo de lo otro no hace referencia tan solo a elementos estéticos sino que, por el contrario, encarna en un sentido muy profundo la alteridad que tales elementos anuncian: el dios "Instala en el centro de la vida pública comportamientos religiosos que, bajo una forma alusiva, simbólica o abierta, presenta rasgos de excentricidad" (Vernant: 2001, 69). En Las Bacantes las mujeres iniciadas son definidas en varias ocasiones como aguijoneadas por la locura. Esta locura de los iniciados muestra la cara dulce y alegre del dios en contraposición a esa otra, oscura e insana, que posee a quien le desafía ${ }^{5}$. Así, podemos afirmar con Walter Otto que "Las prácticas de culto nos dan puntual noticia de su aparición, que agita al mito de un modo tan apasionado. Lo muestran como el que llega, el

\footnotetext{
3 "El carro tirado por panteras y adornado con pámpanos y hiedra, los silenos y las bacantes, los sátiros y otras divinidades menores, tales como Príapo, el dios de Lámpsaco” (Grimal: 2010, 140)

4 "Es posible que se haya hecho demasiada literatura con relación a la antítesis Apolo-Dioniso; sin embargo ella existe" (Gernet: 1984, 17).

5 Una de aquellas recurrentes batallas dionisíacas es representada por Eurípides en Las Bacantes. Este drama cuenta la suerte que corre el rey de Tebas, Penteo, que no acepta el culto del dios. Tras negarse a aplicar los consejos del
} 
dios de la epifanía, cuya aparición es mucho más imperiosa y subyugadora que la de cualquier otro dios" (Otto: 1997, 63), en tanto en cuanto la mencionada obra de Eurípides nos da información valiosa acerca de estas prácticas. El mismo Otto hace referencia a un coro de la Antígona de Sófocles ${ }^{6}$ que demostraría cómo Dioniso hace su aparición por petición expresa de los fieles, a raíz de llamadas, a diferencia de los otros dioses, que casi siempre permanecen invisibles. A este respecto, y de nuevo con Otto, es preciso notar cómo la algarabía es un elemento propio de nuestro dios. Una algarabía capaz de causar espanto y admiración gracias a su enorme fragor. Una algarabía que, como ya se adivinará, tiene una estrecha relación con la locura. Ante todos estos datos se hace cada vez más comprensible el apelativo de Gernet: Dioniso es lo otro porque es un dios a medias extranjero y a medias griego, a medias hombre y a medias mujer, a medias dulce y a medias temible, que por un lado está ligado a las raíces más profundas de la vida y por el otro representa también el oscuro universo de la muerte. Un dios ambiguo: el dios de la alteridad. Tal imagen, la de la alteridad, es afrontada por el hombre griego a través de la máscara. La alteridad de la muerte y la que diluye los límites de la condición humana serían representadas por la Gorgona y Dioniso respectivamente. Esto podría ser entendido como alteridad vertical en contraposición a otra horizontal, la propia de las etapas y transiciones de la vida, representada por Artemisa, quien mediante el lento aprendizaje que supone el paso de la niñez a la madurez conduce al joven griego a su integración positiva en la vida cívica. Dioniso hace estallar en y mediante rituales transgresivos ${ }^{7}$ lo que ella ha unido con su lentitud y su moderación. De entre las tres divinidades (la Gorgona, Artemisa y Dioniso) que en el universo griego tienen una estrecha relación con la máscara, es precisamente nuestro dios el que ocupa el papel más importante. Según Vernant y Vidal-Naquet es "la divinidad cuyas afinidades con la máscara son tan íntimas en todos los aspectos, que ocupa en el panteón griego el lugar del dios de la máscara" (Vernant: 1989, 30) ${ }^{8}$. Con el fin de terminar de entender cuál es la relación entre alteridad y máscara, y por consiguiente cual es el alcance de Dioniso en este sentido, echemos un vistazo a las siguientes palabras:

adivino Tiresias, de su abuelo Cadmo, y del propio Dioniso, que juega un importante papel en el drama bajo la forma de un extranjero enmascarado, acaba llevando la desgracia a los suyos y a sí mismo (su madre, Ágave, le corta la cabeza en un arranque de locura), pues Dioniso nunca deja impune a quien se opone a él.

6 “ih, tú que organizas los coros de los astros que exhalan fuego, guardián de las voces nocturnas, hijo retońo de Zeus, hazte visible, oh señor, a la vez que tus servidoras las Tiíades, que transportadas, te festejan con danzas toda la noche, a ti, Yaco, el administrador de bienes!" (Sófocles: 1981, 292)

7 "Anulando las prohibiciones, confundiendo las categorías, desintegrando las instituciones sociales" (Vernant: $1989,45)$ Otto lo expresa de la siguiente manera: "lo ajeno y lo hostil conviven en sorprendente armonía. Las normas ancestrales pierden de pronto su razón de ser, e incluso las medidas de espacio y tiempo pierden validez" (Otto:1997, 73)

${ }^{8}$ Para terminar de ver la relación de las otras dos divinidades con la máscara sinteticemos con unas líneas la concepción que de ellos tienen los autores franceses: la Gorgona sería "una potencia que es máscara por entero, que 
La máscara expresa la alegría de las sucesiones y reencarnaciones, la alegre relatividad y la negación de la identidad y del sentido único, la negación de la estúpida autoidentificación y coincidencia consigo mismo; la máscara es una expresión de las transferencias, de la metamorfosis, de la violación de las fronteras naturales, de la ridiculización, de los sobrenombres; la máscara encarna el principio del juego de la vida, establece una relación entre la realidad y la imagen individual, elementos característicos de los ritos y espectáculos más antiguos. (Bajtin: 1974, 42).

\subsection{La autonomía de la religión dionisiaca}

Comentando un libro de H. Jeanmarie, Gernet ha dicho que el dionisismo es un movimiento religioso bruscamente expansivo y revolucionario. El propio dios lleva a cabo una lucha durante parte de su vida para que su culto sea instaurado y reconocido en diversas ciudades. "Y este dios nuevo de quien tú te mofas, me resultaría imposible decir de una vez todo lo grande que será en Grecia” (Eurípides: 2007, 24), advierte el adivino Tiresias en Las Bacantes. Como ya se ha dicho, el dios muestra dos caras al respecto según se le acepte o no (valga observar la suerte de Penteo) lo cual viene a decir que aquella parcela de la cultura griega que podemos entender como dionisismo no es más que una religión polimorfa que se dirige al individuo y que posee, a la vez, un aspecto de insoslayable universalidad. Como otros estamentos más o menos separados de la religión griega, el dionisismo propone una posición más estrecha para el hombre respecto de la divinidad, que se funda en lo que podemos entender como éxtasis y entusiasmo (es decir, salida y posesión). Sin embargo, el dionisismo "no favorece la huida fuera del mundo ni pretende ofrecer a las almas, mediante un tipo de vida ascético, el acceso a la inmortalidad; por el contrario, los hombres deben aceptar su condición de mortal, saber que no son nada frente a los poderes que los desbordan por entero y pueden aplastarlos" (Vernant: 1989, 279). Dioniso, que es capaz de disolver las fronteras entre bestia, hombre y dios, reivindica que esto forme parte de un culto cívico y no marginal. En un plano social el dionisismo ha de ser integrado en la propia ciudad, que a su vez le impone también ciertos límites:

Celebrar solemnemente con la comunidad entera las fiestas de Dionisos; organizar para las mujeres una forma de trance controlado, dominado, ritualizado, en el marco de las tiases oficializadas y promovidas a instituciones públicas; desarrollar para los hombres, en la alegría del cômos, por el vino y la embriaguez, el juego y la fiesta, la mascarada y el disfraz, la experiencia de un extrańamiento del curso normal de las cosas; fundar, en fin, el teatro en cuya escena toma cuerpo y se anima la ilusión, y lo ficticio se presenta como

actúa a través de la máscara, en y por ella"(Vernant: 1989, 30). Artemisa "a pesar de que nunca es representada por la máscara, reserva un lugar importante a máscaras y disfraces en su culto”(Vernant: 1989, 30). 
si fuera realidad: en todos los casos se trata, integrando a Dionisos en la ciudad y en su religión, de instalar al Otro, con todos los honores, en el centro del dispositivo social. (Vernant: 2001, 72).

Ahora bien, hoy sabemos que tales cultos debieron suponer, para un griego de la época clásica, cierta diferencia con aquellos otros de la religión tradicional. Se ha dicho de Dioniso que es un dios más democrático que otros, lo que tiene importancia tanto para la comprensión de la religión dionisíaca como para la comprensión de nuestro tema de estudio. Esto puede ser entendido desde la perspectiva individual de aquella; al fin y al cabo Dioniso es el dios que viene, el dios que responde a las llamadas de los mortales, que brinda a cada uno, si sabe aceptarle, un vis a vis con lo sagrado a partir de sí mismo ${ }^{9}$. Desde el punto de vista de la colectividad es útil señalar la división religiosa con la que los estadistas del siglo VI (Solón, Pisístrato y Clístenes) han de lidiar: si la aristocracia rural va a estar relacionada con la religión homérica y sobretodo con el culto a los héroes, el pueblo va a romper una lanza a favor de nuestro dios. Más allá de ello, Dioniso se ha dirigido en especial a quienes no se encuentran arropados institucionalmente en el marco de la polis.

La religión de Dionisos es en primer lugar asunto de mujeres. Las mujeres como tales son excluidas de la vida política[...] Los esclavos encuentran también en los cultos a Dionisos un lugar que les está normalmente negado. Por último, los mismos términos de thiasos y orgeon, que designan los colegios de fieles asociados en las orgías, retienen el recuerdo de grupos campesinos, en relación con el demos primitivo, y que, oponiéndose a los gene nobiliarios que viven en la ciudad y que controlan el estado, tendrán que luchar duramente para hacerse admitir en las fratrías de la época histórica. (Vernant: 2013, 319).

\section{El tema de la tragedia}

Al ACABAR NUESTRA SECCIÓN anterior hacíamos referencia a una división religiosa que respondía a cierto cambio respecto de los estratos sociales así como a cierta confrontación entre ellos ${ }^{10}$. Dado que hablar de los orígenes de la tragedia desde un

\footnotetext{
${ }^{9}$ Es de suma importancia hacer en este punto un pequeńo inciso que aclare esta acepción de "individual", pues pudiera llevar a engaño: la fusión con el dios no se realiza de manera personal, en la soledad de la meditación o mediante un diálogo privado. Por el contrario, cuando el dios se apodera de alguien mediante la excitación le despoja de sí mismo, le convierte en otro (recordemos la relación de nuestro dios con la máscara, que es el medio con el que los griegos representan la alteridad). Por estas razones, es preciso repetir una y otra vez que la relación de uno con Dioniso se lleva a cabo mediante el grupo y mediante, como ha dicho Vernant, técnicas de frenesí colectivo que incluyen "danzas, saltos, cantos y gritos, correrías vagabundas que internan al hombre en plena naturaleza salvaje" (Vernant: 2013, 320). Cuando nosotros hacemos referencia a aquella individualidad nos referimos esencialmente a la capacidad de cualquiera para reconocer, aceptar y experimentar al dios.

${ }_{10}$ Por una parte, hemos de decir que las reformas políticas de Clístenes arrebataron a la aristocracia ciertos privilegios de clase al dejar de reconocer institucionalmente su vinculación al genos en favor de una organización más geográfica. Esto, como ha de notar Vernant, tiene su explicación en el hecho de que con el advenimiento
} 
punto de vista demasiado autorreferencial carece de sentido en la medida en que carece de soportes físicos, podemos afirmar, con Vernant y Vidal-Naquet, que tales orígenes residen en aquella división. Si acaso, podríamos precisar aún más yendo a lo más concreto de tal origen político: Clístenes de Sición rivaliza con los argivos al dedicar al héroe Melanipo una serie de ofrendas y fiestas en las que se cantaba a sus vicisitudes por medio de coros trágicos atribuidos a Dioniso. El quid de tal rivalidad no es otro que el hecho de que los argivos hacían lo propio con Adrastro, enemigo mortal de aquel. Sea como fuere, lo que realmente nos interesa, como origen sin más, es que hacia el año 534 a.C. Tepsis representa por primera vez una tragedia en las Grandes Dionisias y que, más allá del hecho particular, a partir de entonces nuestro espectáculo queda instituido como parte integrante del culto estatal.

\subsection{La encrucijaza de la decisión}

El VERDADERO SIGNIFICADO DE LA TENSIÓN RELIGIOSA a la que hacíamos referencia no se queda únicamente en una oposición estética y estática entre distintas tendencias sino que, como ha dicho cierto autor francés, la tragedia nace cuando se empieza a contemplar el mito con ojos de ciudadano. Nuestro género literario supone, pues, un cuestionamiento del hombre por el hombre mismo. Penetrando con un poco más de profundidad en las reformas de Clístenes descubriremos cuál es el auténtico alcance de tal cuestionamiento: las cuatro tribus jónicas del Ática (según Aristóteles relacionadas con las cuatro estaciones) son sustituidas por diez, cada una de las cuales agrupa tres trittias que a su vez se dividen en demos. Tal división, en contraposición a la organización anterior, agrupa a los ciudadanos por proximidad geográfica y deja de lado (al menos institucionalmente) lo relativo a la sangre, de forma que cada tribu unifica políticamente las diferentes actividades que componen la ciudad (esto se entenderá mejor si apostillamos que cada una de las tres trittias propias de cada tribu corresponde a una región diferente: costa, interior y urbe). Estas reformas, junto con la del calendario (aunque el lunar sigue rigiendo los acontecimientos religiosos, el gobernador crea uno civil, al margen, con la fi-

de una nueva mentalidad propiciada por el nacimiento de un nuevo tipo de ciudadano, naturaleza y sociedad dejan de ser explicadas y organizadas desde la misma perspectiva (dejan de identificarse), tal como hacía el mito. Además, se ha de señalar como detonante de importancia central el florecimiento de una nueva clase social hasta entonces denostada como es (valga el anacronismo) la burguesía. Esto, lejos de ser un hecho aislado, se puede rastrear también en otros tiempos y lugares; por ejemplo, Japón pasa del feudalismo a la economía de mercado debido a la llamada Reforma Meiji, que tiene lugar gracias a la unión de pequeños samurai con una burguesía hasta entonces considerada como paria (véase El crisantemo y la espada (Benedict: 2013). En la Atenas del siglo de Pericles no son otros que los metecos (extranjeros), con un estatus a caballo entre los esclavos y los ciudadanos, quienes se dedican a los negocios para que estos, los verdaderos atenienses, puedan dedicarse a la política. 
nalidad de organizar mejor la administración otorgando a cada tribu el derecho de formar, durante un periodo de tiempo determinado, la comisión permanente del consejo), buscan más una eficiencia política que una estrecha compenetración entre ciudad y cosmos.

La tragedia, no obstante, no se sitúa de lleno en este nuevo mundo con intención de destruir el viejo, por el contrario juega en ambos tableros. Un arte propiamente trágico es el que expresa un conflicto de valores. Ambos universos, el del mito y el de la polis, pierden consistencia al existir, en cada uno de los personajes trágicos, una tensión psicológica interna que viste a todos los valores expresados por boca de los protagonistas con un traje de calculada ambigüedad ${ }^{11}$. El héroe trágico pone tales valores sobre la mesa mediante una decisión que reposa sobre aquella ambigüedad, evidenciando una responsabilidad impuesta que pesa como una losa debido a que sus propios actos escapan a sí mismo y le superan, de manera que hasta el final del drama no se descubre su verdadera significación (de hecho esta cuestión es a la que Aristóteles se refiere como anagnórisis o reconocimiento en su Poética):

¿Cómo podría comprender Edipo que se refería a sí mismo ese enigma, cuyo sentido no adivinará más que descubriendo ser lo contrario de lo que creía, no el hijo de la Tyché, sino su víctima, no el justiciero, sino el criminal, no el rey salvador de su ciudad, sino la abominable mácula por la que está pereciendo? (Vernant: 1989, 40) ${ }^{12}$.

Vemos, pues, que el agente trágico no tiene una autonomía propia en tanto en cuanto es, por un lado, causa responsable de sus actos y por el otro un juguete a merced de los dioses. En este sentido la hamartía o error trágico, que puede ser considerada como el detonante implícito de la acción, consiste en un acto que entraña una locura ${ }^{13}$ que penetra al individuo con lo que Vernant ha llamado una fuerza religiosa maléfica, la cual se extiende más allá de él, quedando vinculada también a su estirpe (por continuar con el ejemplo de los Labdácidas pensemos en la desgraciada Antígona, que debido a que las desventuras de su padre Edipo desencadenan una pugna entre sus hermanos se ve abocada a tener que elegir entre quebrantar las leyes de los dioses o quebrantar las leyes de la ciudad). De esta manera la culpabilidad trágica, al igual que el agente trágico, se desarrolla según dos principios del todo

${ }^{11}$ Esta tensión se ha de notar también en el propio lenguaje del héroe y del coro. Mientras que el héroe (pese a pertenecer al antiguo mundo de valores) se expresa con un lenguaje claro y transparente, el coro (que representa al pueblo) se expresa por medio de un lenguaje oscuro debido, quizás, a su relación con el ditirambo.

12 Se refiere a la solución que propone Delfos a la peste que azota al pueblo de Tebas: encontrar al asesino de Layo, padre de Edipo. Lo que ocurre después es de sobra conocido: Creonte y Tiresias son acusados de traición por Edipo, quien, más tarde y gracias al veredicto de un pastor, acaba descubriendo que él mismo es el asesino de su padre, y el que yace en el mismo lecho que su madre.

13 Además de locura también entrańa ignorancia. Para comprobarlo basta con echar un vistazo al ejemplo anterior, pues Edipo aun creyendo ser aquel que desvela los enigmas es en realidad un ignorante. 
diferentes: la responsabilidad intencional en los actos y la mediación de los dioses respecto de aquellos.

\subsection{Tragedia y filosofía}

EN TANTO EN CUANTO venimos considerando a la tragedia como a una especie de crítica al hombre de su tiempo, creemos que es pertinente compararla con otro género literario que empieza a despuntar, como género específico, en el momento mismo en el que la tragedia inicia su declive; la filosofía. Es pertinente, decíamos, porque esta también supone una crítica al hombre (o más bien al lugar del hombre en el cosmos). Pero antes de que un personaje chato y poco aseado lleve el debate abstracto sobre la moral al mismomísimo corazón del ágora, la disciplina (si es que puede llamarse así) ha ido quemando sus propias etapas desde un tiempo y un lugar muy remotos.

Quizás la tesis fundamental de Vernant haya sido que el hombre griego construye la razón a partir del (que no en contraposición al) mito ${ }^{14}$, aunque esto también lo ha postulado Giorgio Colli en un pequeño libro. Más allá de lo evidente de tal tesis, el interés que nosotros ponemos en ella tiene que ver con la idea de que la filosofía (al igual que la nueva polis de Clístenes) intenta romper el molde del mito para desembarazarse de él mientras que la tragedia no termina de dejarlo marchar. Esto no arroja nueva luz sobre el tema de lo trágico, pero nos ayuda a encuadrarlo en su vertiente religiosa. La tragedia es parte integrante del culto cívico vivo y el trágico un personaje respetado a diferencia del filósofo, que deriva de un tipo de hombre que ya no encarna: el mago ${ }^{15}$. Las características de este personaje (legendario y profundo, perteneciente a una época concreta y pasada) difieren de las del filósofo en tanto en cuanto la sabiduría trata de resolver enigmas (de revelar lo que está oculto) y la filosofía mezcla dialéctica y retórica con escritura y ambiciones políticas y educativas (es decir, el elemento agónico y la preocupación por la verdad abstracta con las preocupaciones mundanas) en un alarde de melancolía ilustrada. Cuando Platón se define como filósofo se está retratando como aquel que ama la sa-

${ }_{14}$ De ahí que muchas de sus obras formulen, en sus títulos, la cópula Mito y(...). Para entender cómo se va construyendo la razón a partir del mito véase el artículo Del mito a la razón en Vernant: 2013, 334-365, donde se explica pormenorizadamente la relación entre las estructuras de algunos textos de Hesíodo y las protofilosofías de Anaxímenes o Anaximandro. El quid de la cuestión está en que tanto el poeta como los filósofos de la naturaleza parten de la siguiente pregunta: ¿Cómo un mundo ordenado ha podido emerger del caos?

15 Viene bien recordar que todavía en los años del ocaso de la tragedia, la sociedad griega, aun con el enorme cambio de mentalidad y valores al que había sido sometida, sigue siendo una sociedad francamente religiosa. Tanto es así, que declarar, como nosotros lo hemos hecho, que el trágico es un personaje respetado son palabras mayores. Así como Sócrates se vio obligado a beber cicuta debido a su impiedad, los trágicos no se vieron libres 
biduría porque no la posee, como aquel, por tanto, que la busca. Para considerar al elemento dialéctico (que es quizás el elemento decisivo) en todas sus dimensiones, nos parece útil traer a colación las siguientes palabras de Colli acerca del enigma:

Primero el dios inspira una respuesta en forma de oráculo, y el profeta, por decirlo con Platón, es un simple intérprete de la palabra divina, pertenece todavía totalmente a la esfera religiosa. Después el dios impone un enigma mortal a través de la Esfinge, y el hombre particular debe resolverlo o, de lo contrario, perderá la vida. Por último, dos adivinos, Calcante y Mopso, luchan entre sí por un enigma: ya no interviene el dios, queda el fondo religioso, pero interviene un elemento nuevo, el agonismo, que en este caso es una lucha por la vida y por la muerte. Un paso más, y cae el fondo religioso, y ocupa el primer plano el agonismo, la lucha de dos hombres por el conocimiento: ya no son adivinos, son sabios, o mejor combaten por conquistar el título de sabio. (Colli: 1983, 49) ${ }^{16}$.

El elemento agónico supone, pues, un esqueleto para la dialéctica al igual que el enigma supone su matriz. En este sentido, y considerando el hecho de que para un antiguo sabio la derrota es una humillación intolerable (Aristóteles nos cuenta que Homero murió por no saber resolver un enigma planteado por unos pescadores), cabe entender a la dialéctica como a un elemento capaz de humanizar progresivamente al enigma de modo que el fondo religioso deje paso a un discurso abstracto, racional y demostrativo. En el momento en que un discurso de estas características es trasladado al ágora y atado al elemento moral (pensemos en Sócrates) nos encontramos ante una crítica al hombre que poco tiene que ver con la que planteaba la tragedia: la filosofía, gracias a su esqueleto dialéctico, rechaza la contradicción mientras que la tragedia la busca. Recordemos que nuestro género literario dibuja las oposiciones propias de una experiencia social hecha jirones:

Así, vemos en Las Suplicantes oscilar la noción de krátos entre dos concepciones contrarias sin poder fijarse en una o en otra. En la boca del rey Pelasgo, krátos, asociado a kýrios

de acusaciones parecidas (aunque en ningún caso llegase la sangre al río). Sin embargo, según nos cuenta Robert Flacelière, los magistrados más importantes eran los encargados de preparar las representaciones, seleccionando a los coregos, que eran quienes gracias a su riqueza formaban, mantenían y equipaban a los coros trágicos (y cómicos). A cada poeta le era asignado un coro, un protagonista, un deuteragonista y un tritagonista, y tras la celebración del concurso (que consistía en la representación por parte de cada poeta de una trilogía trágica más una tragicomedia) las decisiones relativas a la asignación debían rendir cuentas ante el escenario.

${ }^{16}$ El espíritu dialéctico, sin embargo, no concluye en este punto. Mediante esta cita hemos pretendido mostrar como tal elemento evoluciona desde una dimensión exclusivamente religiosa, propia del oráculo y de una cultura muy antigua, hacia una dimensión agónica en la que la victoria está a la altura de la revelación. Esta, por decirlo con Colli, razón destructiva tiene su dique en Parménides, ese sabio preocupado por lo abstracto que neutraliza a aquella con la pregunta ¿Es o no es? Sin embargo, el filósofo, como se ha dicho, hereda esa preocupación por lo abstracto a la par que la fogosidad dialéctica en su contexto agónico hasta tal punto que, de nuevo según Colli, los diálogos de Platón no serían sino un pálido reflejo de lo que aquello realmente significaba: la celebración, en la plaza pública, de una especie de espectáculo en el que la victoria consistía en la contradicción por parte del interrogado de su propia tesis debido a la habilidad demostrativa del interrogador. 
(señor), designa una autoridad legítima, el dominio que ejerce con pleno derecho el tutor sobre aquel que jurídicamente depende de su poder; en boca de las Danaides la misma palabra, atraída al campo semántico de la bia (violencia), designa fuerza brutal, la coacción de la violencia en su aspecto más opuesto a la justicia y el derecho. (Vernant: 1989, 33-34).

Sirva el ejemplo de Las Suplicantes de Esquilo para demostrar que esta lógica contradictoria no es un invento de la hermenéutica sino algo que tiene unas profundas raíces filológicas. Esto, como hemos dicho, supondría algo insidioso para un pensamiento filosófico que es a su vez pensamiento positivo (es decir, que rechaza la asimilación entre fenómenos físicos y agentes divinos) y, más importante, pensamiento abstracto (es decir, que rechaza la vieja imagen de unión de los contrarios en favor de una formulación categórica del principio de identidad).

\section{Conclusiones: ¿en qué atañe esto a Dioniso?}

TOCA AHORA, AL MODO DEL RAPSODA, hilar los diferentes apartados de nuestro texto con el fin de concederles un sentido. Ha quedado claro que la tragedia, como género literario, manifiesta un conflicto de valores que tiene que ver con lo religioso y con un profundo cambio en la organización social. Sin embargo, es ya un clásico citar un antiguo refrán griego que manifiesta el mismo asombro que puede sentir el lector contemporáneo a la hora de reflexionar sobre este extraño género: nada aqui atañe a Dioniso. Tal asombro se agudiza aun más si cabe en el caso del lector familiarizado con la obra de Nietzsche, ya que el filósofo errante quiso ver en su Nacimiento de la tragedia un trasfondo dionisíaco muy presente en los dramas de Esquilo y de Sófocles, que se oponía de manera férrea a aquel otro, el apolíneo, del que Sócrates se erige en representante al formular de manera errada la famosa máxima délfica del conócete a ti mismo ${ }^{17}$.

Efectivamente, quizás la interpretación nietzscheana tenga más de ficción que de verdad, y es que, como dice un bello pasaje de Hermann Hesse, sobre literatura se habla poco y se miente mucho. Vernant ha señalado que "la verdad de la tragedia no reside en un oscuro pasado, más o menos primitivo o místico que seguiría frecuentando en secreto la escena del teatro, sino que se descifra en todo lo que la tragedia ha aportado de nuevo y original en los tres aspectos en que ha modificado el hori-

\footnotetext{
17 Apolo y Dioniso, "estos nombres representan antítesis estilísticas que caminan una junto a otra, casi siempre luchando entre sí, y que sólo una vez aparecen fundidas, en el instante del florecimiento de la voluntad helénica, formando la obra de arte de la tragedia ática” (Nietzsche: 2009, 244). Este fragmento demuestra que el trasfondo apolíneo también llena las obras de aquellos dos trágicos, y que de hecho la tragedia es, para Nietzsche, la representación de la sabiduría dionisíaca a través de formas apolíneas.
} 
zonte de la cultura griega" (Vernant: 1989, 23) ${ }^{18}$. Aun con todo, el inteligentísimo análisis de Nietzsche resulta muy valioso en tanto en cuanto confiere a lo dionisíaco y a lo apolíneo un estatus metafísico al que, no obstante, seguramente le sobre el componente hiperestetizado. Que la metafísica está estrechamente relacionada con el teatro no debería sorprender a nadie si entendemos a aquella como cosmovisión, al drama como parte integrante del culto religioso y a la religión como elemento cuya finalidad es, precisamente, articular cosmovisión y ethos, es decir, visión del mundo y modo de acción. En este sentido se hace perfectamente comprensible el enfado de Nietzsche con un poeta como Eurípides, que propicia un giro en el devenir de la tragedia al alejar a la música (es decir al coro, heredero directo del ditirambo que presenta un mundo esencialmente pesimista) del drama, y al revestir a sus personajes de un insidioso optimismo dialéctico. En cuanto acontecimiento religioso, la tragedia euripídea engendra y justifica un modo de acción que es, según Nietzsche, el comienzo mismo de la decadencia de occidente, el germen de la civilización socrático-alejandrina. En este sentido, y como dice el antropólogo norteamericano Clifford Geertz, "la moral tiene pues el aire de un simple realismo, de un saber práctico; la religión presta apoyo a la conducta apropiada al pintar un mundo en el cual dicha conducta es solo producto del sentido común" (Geertz: 1992, 121). Sin embargo, aunque la religión (e insistimos en la idea de que la tragedia es un acontecimiento religioso) confiere a los valores una apariencia de objetividad, la peculiaridad de nuestro género literario reside precisamente en la propia ambigüedad de los valores que representa. La tensión de la acción trágica no desemboca en una conclusión fuerte que impulse al espectador a introyectar inconscientemente cierto ethos por encima de otro. Más allá, y como el teatro de sombras javanés respecto de los javaneses, la tragedia dramatiza la psicología metafísica propia de un hombre griego en crisis.

En cuanto a Dioniso, la pregunta sigue y seguirá eternamente abierta. Partiendo del hecho de que nuestro propósito es tan humilde que no hemos pretendido descubrir nada oculto ni postular ninguna teoría novedosa, lo mejor que podemos hacer es acabar con unas palabras de la obra de Vernant, de la cual este texto no es sino una apostilla más o menos extensa:

$\mathrm{Si}$, como nosotros creemos, uno de los principales rasgos de Dioniso consiste en desdibujar constantemente las fronteras entre lo ilusorio y lo real, en suscitar repentinamente el más allá en este mundo, está claro que el rostro del dios nos sonríe, enigmático y ambiguo, en este juego de ilusión teatral que la tragedia instaura, por primera vez, en el escenario griego. (Vernant: 1989, 25).

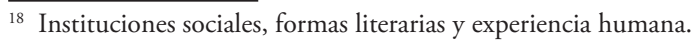




\section{Referencias Bibliográficas}

Alsina, José (1971), Tragedia, religión y mito entre los griegos, Barcelona, Labor Aristófanes (2005), Los Pájaros, Las Ranas, Las Asambleistas, Madrid, Alianza Aristóteles (2011), Poética, Magna moralia, Madrid, Gredos

Bajtín, Mijail (1974), La cultura popular en la edad media y en el renacimiento: el contexto de François Rabelais, Barcelona, Barral

Colli, Giorgio (1983), El nacimiento de la filosofía, Barcelona, Tusquets

Esquilo (2005), Tragedias completas, Madrid, Cátedra

Eurípides (2007), Las Bacantes, Madrid, Ediciones Clásicas

Eurípides (1977), Tragedias I, Madrid, Gredos

Eurípides (1977), Tragedias II, Madrid, Gredos

Flaceliére, Robert (1989), La vida cotidiana en Grecia en el siglo de Pericles, Madrid, ETH

Geertz, Clifford (1992), La interpretación de las culturas, Barcelona, Gedisa

Gernet, Louis (1984), Antropología de la Grecia antigua, Madrid, Taurus

Grimal, Pierre (2010), Diccionario de mitología griega y romana, Madrid, Paidós Lesky, Albin (1976), Historia de la literatura griega, Madrid, Gredos

Nietzsche, Friedrich (2009), El nacimiento de la tragedia, Madrid, Alianza

Otto, Walter F. (1997), Dioniso. Mito y culto, Madrid, Siruela

Platón (2004), Ión, Timeo, Critias, Madrid, Alianza

Sófocles (1981), Tragedias, Madrid, Gredos

Vernant, Jean-Pierre (2013), Mito y pensamiento en la Grecia antigua, Barcelona, Ariel

Vernant, Jean-Pierre (2001), Mito y religión en la Grecia antigua, Barcelona, Ariel Vernant, Jean-Pierre y Vidal-Naquet, Pierre (1989), Mito y tragedia en la Grecia antigua I, Madrid, Taurus

Vernant, Jean-Pierre y Vidal-Naquet, Pierre (1989), Mito y tragedia en la Grecia antigua II, Madrid, Taurus

DOI: https://doi.org/10.15366/bp.2020.24.022

Bajo Palabra. II Época. № 24. Pgs: 433-448 